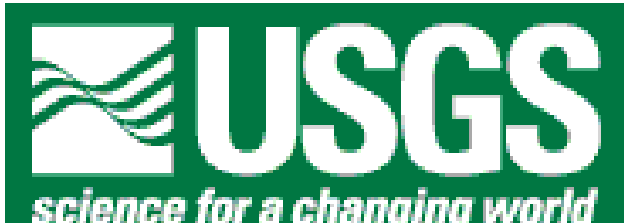

\title{
Flow Patterns and Current Structure at the USS Arizona Memorial: April, 2005
}

U.S. Department of the Interior U.S. Geological Survey

Open-File Report 2005-1334

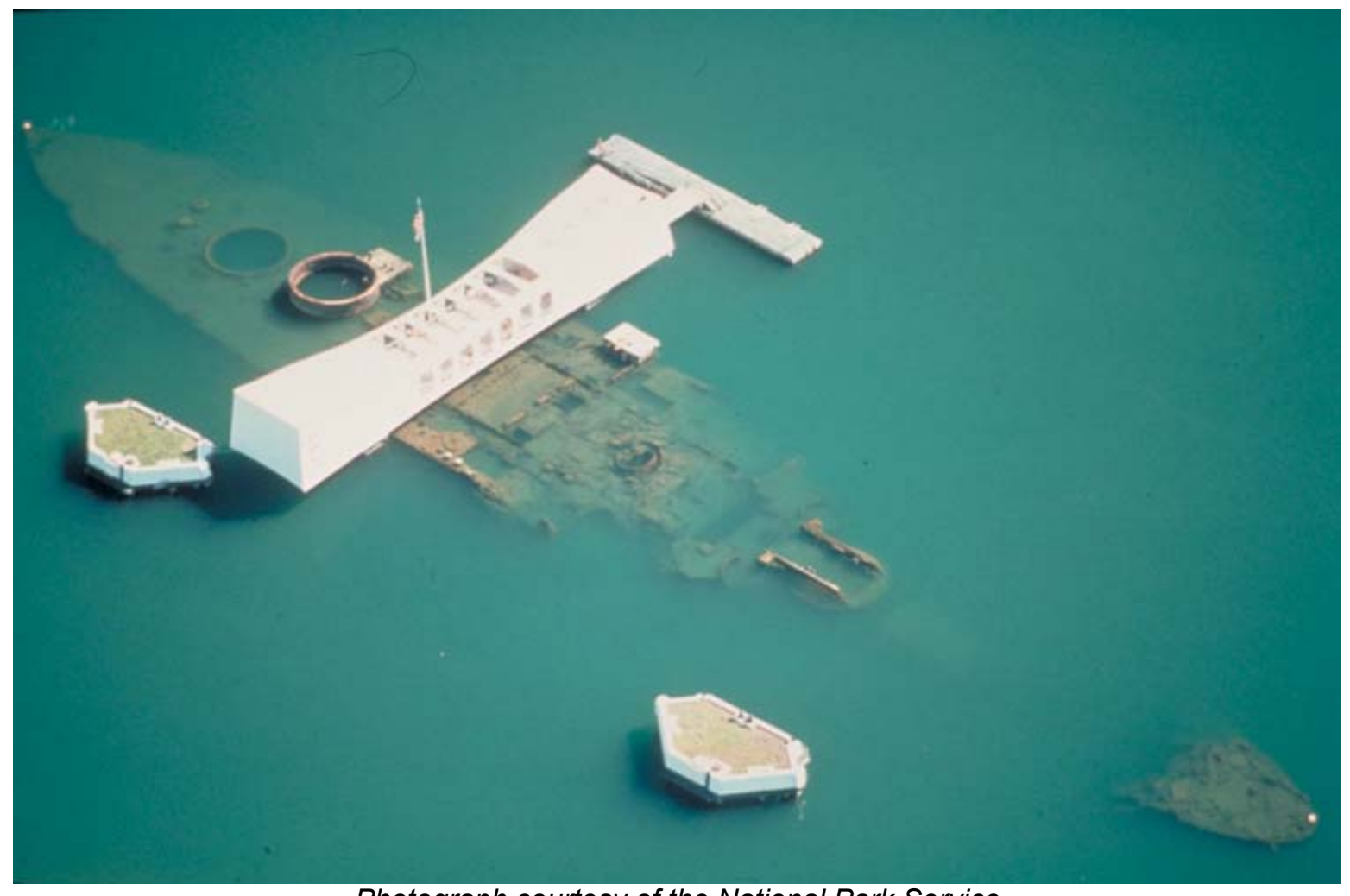

Photograph courtesy of the National Park Service 



\section{Flow Patterns and Current Structure at the USS Arizona Memorial: April, 2005}

Curt D. Storlazzi ${ }^{1}$, Matthew A. Russell ${ }^{2}$, M. Katherine Presto ${ }^{1}$ and Jennifer E. Burbank ${ }^{3}$

${ }^{1}$ US Geological Survey, Pacific Science Center, Santa Cruz, CA

${ }^{2}$ National Park Service, Submerged Resources Center, Santa Fe, NM

${ }^{3}$ National Park Service, USS Arizona Memorial, Pearl Harbor, Oahu, HI

U.S. GEOLOGICAL SURVEY

Open-File Report 2005-1334 


\section{LIST OF TABLES}

TABLE 1. Experiment personnel.

TABLE 2. ADCP deployment log.

\section{LIST OF FIGURES}

FIGURE 1. Map of the study area location in relation to the main Hawaiian Island chain.

FIGURE 2. Map showing location of instrument packages in the study area.

FIGURE 3. Photograph of one of the instrument packages.

FIGURE 4. Relationship between tides, flow and temperature off the starboard side.

FIGURE 5. Mean flow and its variability at different heights above the seafloor off the starboard side.

FIGURE 6. Relationship between tides, flow and temperature off the port side.

FIGURE 7. Mean flow and its variability at different heights above the seafloor off the port side.

FIGURE 8. Relationship between tides, flow and vertical shear off the starboard side.

FIGURE 9. Relationship between tides, flow and vertical shear off the port side.

FIGURE 10. Vertical profiles of current velocity and the resulting current-induced force on the starboard hull.

FIGURE 11. Vertical profiles of current velocity and the resulting current-induced force on the port hull.

FIGURE 12. Concurrent water temperatures of the port and starboard sides of the hull and the resulting thermal gradient.

\section{LIST OF APPENDICES}

APPENDIX 1. Acoustic Doppler Current Profiler (ADCP) Information. 


\section{ADDITIONAL DIGITAL INFORMATION}

For additional information on the instrument deployments, please see:

http://walrus.wr.usgs.gov/infobank/a/a105oa/html/a-1-05-oa.meta.html

For an online PDF version of this report, please see:

http://pubs.usgs.gov/of/2005/1334/

For more information on the U.S. Geological Survey Western Region's Coastal and Marine Geology Team, please see:

http://walrus.wr.usgs.gov/

For more information on the National Park Service's Submerged Resources Center, (NPS-SRC) please see:

http://www.nps.gov/submerged

For more information on the National Park Service's Submerged Resources Center's USS Arizona Memorial Project, please see:

http://www.pastfoundation.org/Arizona

For general information on the USS Arizona National Memorial please see:

http://www.nps.gov/usar/

\section{DIRECT CONTACT INFORMATION}

Regarding this Report

Dr. Curt D. Storlazzi, Oceanographer.

cstorlazzi@usgs.gov

USS Arizona Memorial Project Information

Matthew A. Russell, Project Director:

Larry E. Murphy, Chief, NPS-SRC:

matthew russell@nps.gov

larry murphy@nps.gov

\section{REPORT REFERENCE}

Storlazzi, C.D., Russell, M.A., Presto, M.K. and Burbank, J.E., 2005. "Flow Patterns and Current Structure at the USS Arizona Memorial: April, 2005" U.S. Geological Survey Open-File Report 2005-1334, 24 p. 


\section{INTRODUCTION}

U.S. Geological Survey (USGS) and National Park Service (NPS) personnel collected short-term (1 month), high-resolution physical oceanographic measurements at the USS Arizona Memorial (USAR) in April, 2005, to better understand the nature of flow surrounding the mostly submerged historic ship. Scientists deployed two bottommounted oceanographic instruments in water depths less than $10 \mathrm{~m}$ on either side of the USS Arizona's hull. This study supports the National Park Service's Submerged Resources Center (NPS-SRC) research directed at understanding and characterizing the nature and rate of natural processes affecting deterioration of the National Historic Landmark (NHL) USS Arizona. The purpose of these measurements was to collect high-resolution and spatially-extensive hydrographic data to better constrain the nature of fluid flow around the submerged vessel's hull and near the Memorial.

This project represents a multi-agency approach to acquiring sound scientific data requisite for future stewardship-based management actions. Several organizations cooperatively funded this project: USGS, Department of Defense Legacy Resources Management Fund, NPS Systemwide Archeological Inventory Program, USS Arizona Memorial, Arizona Memorial Museum Association, and NPS Submerged Resources Center.

\section{Project Objectives:}

The objective of the instrument deployments was to understand how currents and temperature in the vicinity of the Memorial vary over 2 spring-neap tidal cycles. These data supplemented the long-term single-point measurements made between 2002 and 2004 by Storlazzi et al., (2004). The oceanographic data were collected to support the NPS-SRC research to understand and characterize the nature and rate of natural processes affecting deterioration of USS Arizona. The USS Arizona, along with USS Utah, was designated as a NHL, the nation's highest recognition of historic significance, on May 5, 1989. The NPS-SRC project was designed to be multi-year, interdisciplinary and cumulative, with each element contributing to developing an overall management strategy designed to provide the basic research required to make informed management decisions for long-term preservation of these NHL sites. Understanding the nature and rate of natural processes affecting deterioration of the vessels is required for sound management decisions regarding long-term preservation of these sites. In addition, the NPS-SRC research program will have global application to the many sunken steel heritage vessels, and it will serve as a management model for NPS and partners who have stewardship responsibility for these sites. As part of this research program, flow patterns close to Arizona's hull were investigated. The two instrument packages were deployed for a period spanning 1 month to investigate both horizontal and vertical spatial variability in flow.

\section{Study Area:}

Instrument deployments were conducted off the northwest corner of Ford Island in the East Loch of Pearl Harbor, South-central Oahu, Hawaii, USA (FIGURE 1). One instrument was deployed in $10 \mathrm{~m}$ of water roughly $25 \mathrm{~m}$ southeast of Arizona's port beam below the Number 1 turret. The other instrument package was deployed in $9 \mathrm{~m}$ of water roughly $25 \mathrm{~m}$ northwest of Arizona's starboard beam below the Number 1 turret 


\section{ZUSGS}

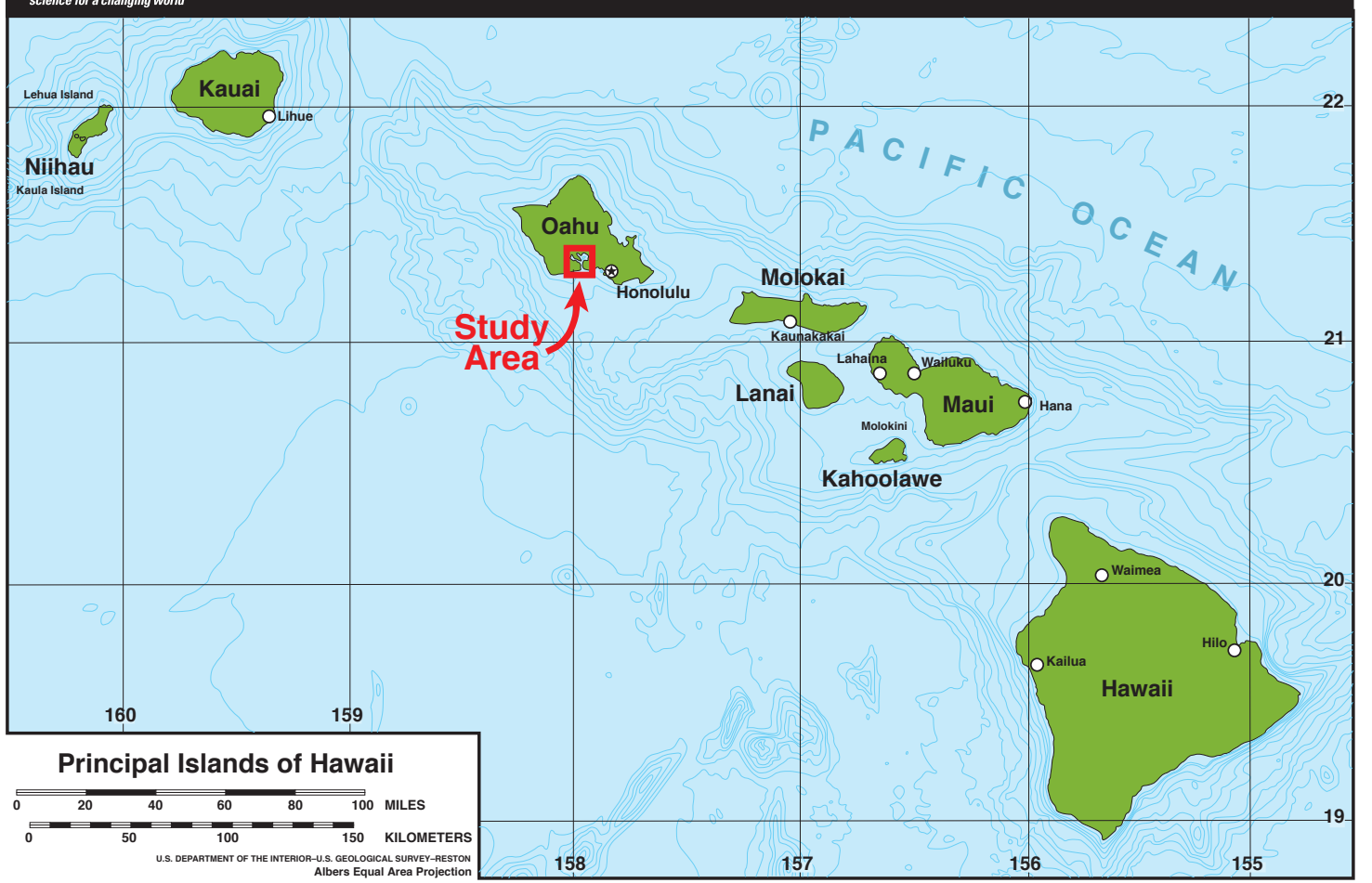

b)

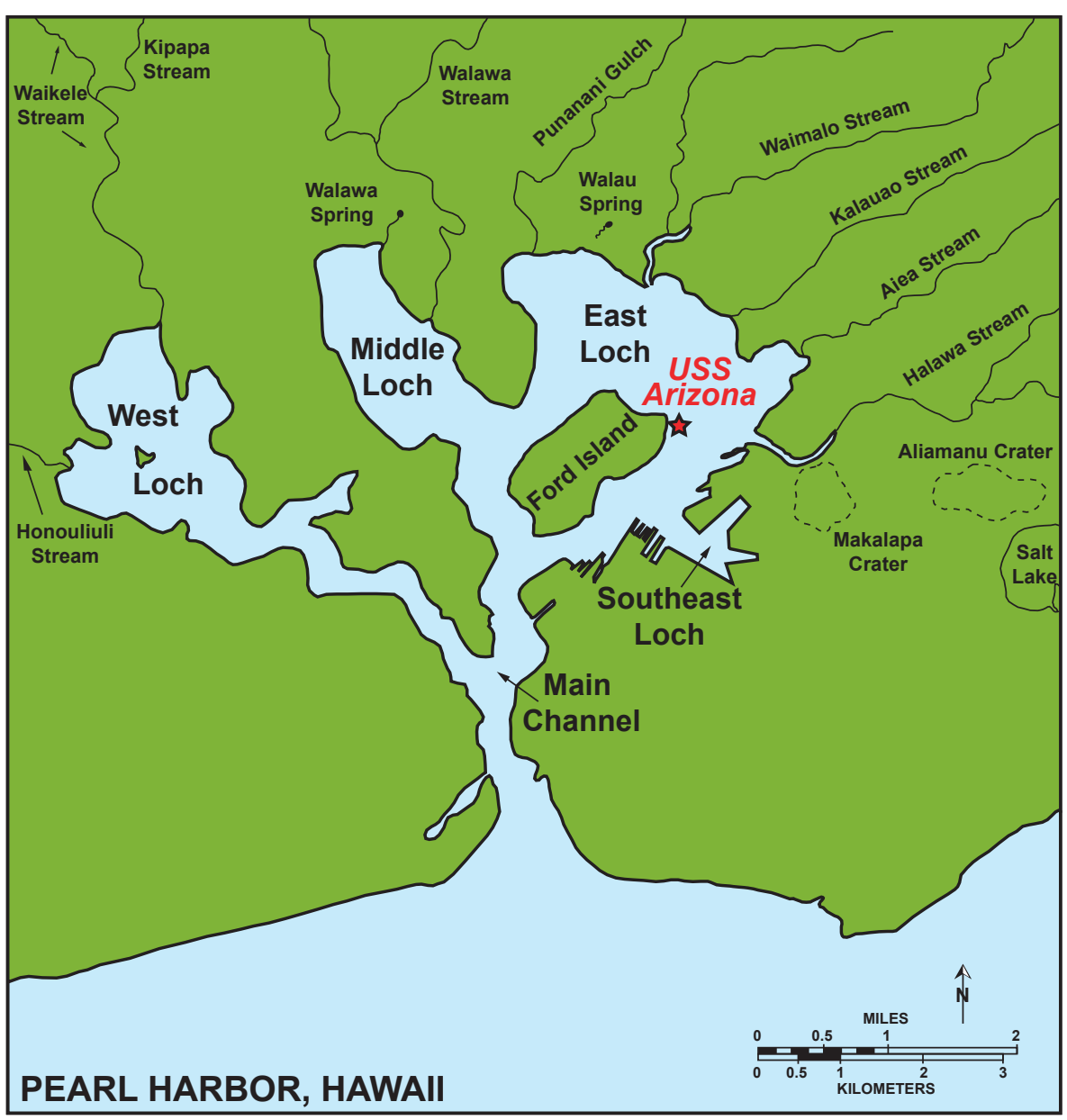

FIGURE 1. Map of the study area. a) Location of Pearl Harbor in relation to the main Hawaiian Island chain. b) Location of the USAR in Pearl Harbor relative to Ford Island, the main Lochs and sources of freshwater that empty into the harbor. 
just to the southwest of the mooring quay (FIGURE 2). The seafloor at these sites consists of an organic-rich mud. All diving, mobilization and demobilization were based from the USAR dock on the eastern side of the East Loch of Pearl Harbor, South-central Oahu, Hawaii.

\section{OPERATIONS}

This section provides information about personnel, equipment and vessels used during equipment deployments. See TABLE 1 for personnel involved in this experiment and TABLE 2 for complete deployment information.

\section{Equipment and Data Review:}

The primary instruments used to acquire data during the deployments were two $\mathrm{RD}$ Instruments $600 \mathrm{kHz}$ Acoustic Doppler Current profilers (ADCP). These collected three-dimensional vertical profile measurements of current speed and direction in $0.5 \mathrm{~m}$ bins (sampling volumes) every $0.5 \mathrm{~m}$ from $1.0 \mathrm{~m}$ above the seafloor up to the water surface and single-point measurements of water temperature $0.5 \mathrm{~m}$ above the seafloor; a pressure sensor on the ADCP measured water level data (FIGURE 3). The ADCP sampled mean currents, water level and water temperature by averaging over a 1-min window every $4 \mathrm{~min}$. The instrument package deployment and recovery log is presented in TABLE 2; the instrument specifics and sampling scheme is listed in APPENDIX 1.

\section{Deployment/Recovery Operations:}

The US Navy operates launches to transport visitors between USAR headquarters and the Memorial about every 15 minutes. The Navy launches transported project scientists and instruments to the USAR dock. Prior to deployment, diving scientists established a secure guideline from Arizona's hull out to the location where the instruments would be deployed. The ADCPs and their semi-permanent mount were deployed by initially lowering them just below the water's surface. At this point the scuba divers attached a lift bag and detached the lifting line. The divers followed a marker line to the sea floor to move the instrument packages into place. They secured the instrument packages with cables attached to sand anchors embedded in the seafloor. Recovery and redeployment operations involved the same procedures.

\section{DATA ACQUISITION AND QUALITY}

Current speed, current direction and near-bed water temperature data were acquired for 30 days between April 2 and May 1, 2005, yielding $100 \%$ coverage over the entire experiment period. Each ADCP made more than 10,400 observations of current speed, current velocity and acoustic backscatter from each of the 28 bins (>290,000 total samples per instrument) over the study period. Data quality was very high. The ADCP data near the surface displayed slightly lower correlation due to bubble interference with the transducers. This loss of data from the bins closest to the surface is common to most upward-looking ADCPs and was expected. The raw ADCP data were archived and copies of the data were post-processed to remove all "ghost" 


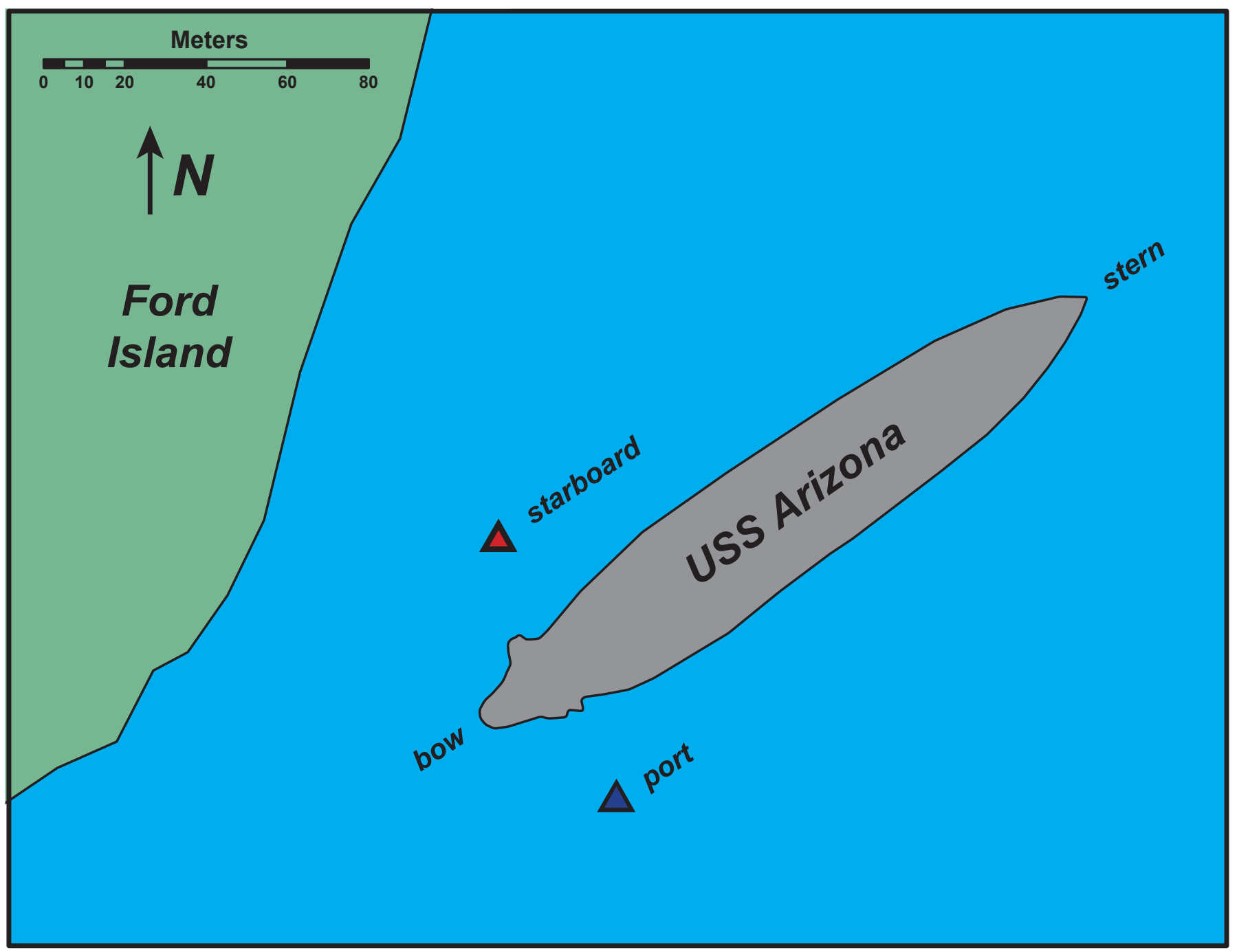

FIGURE 2. Map showing the spatial distribution of instrument packages in the study area relative to the USAR's hull and Ford Island. 


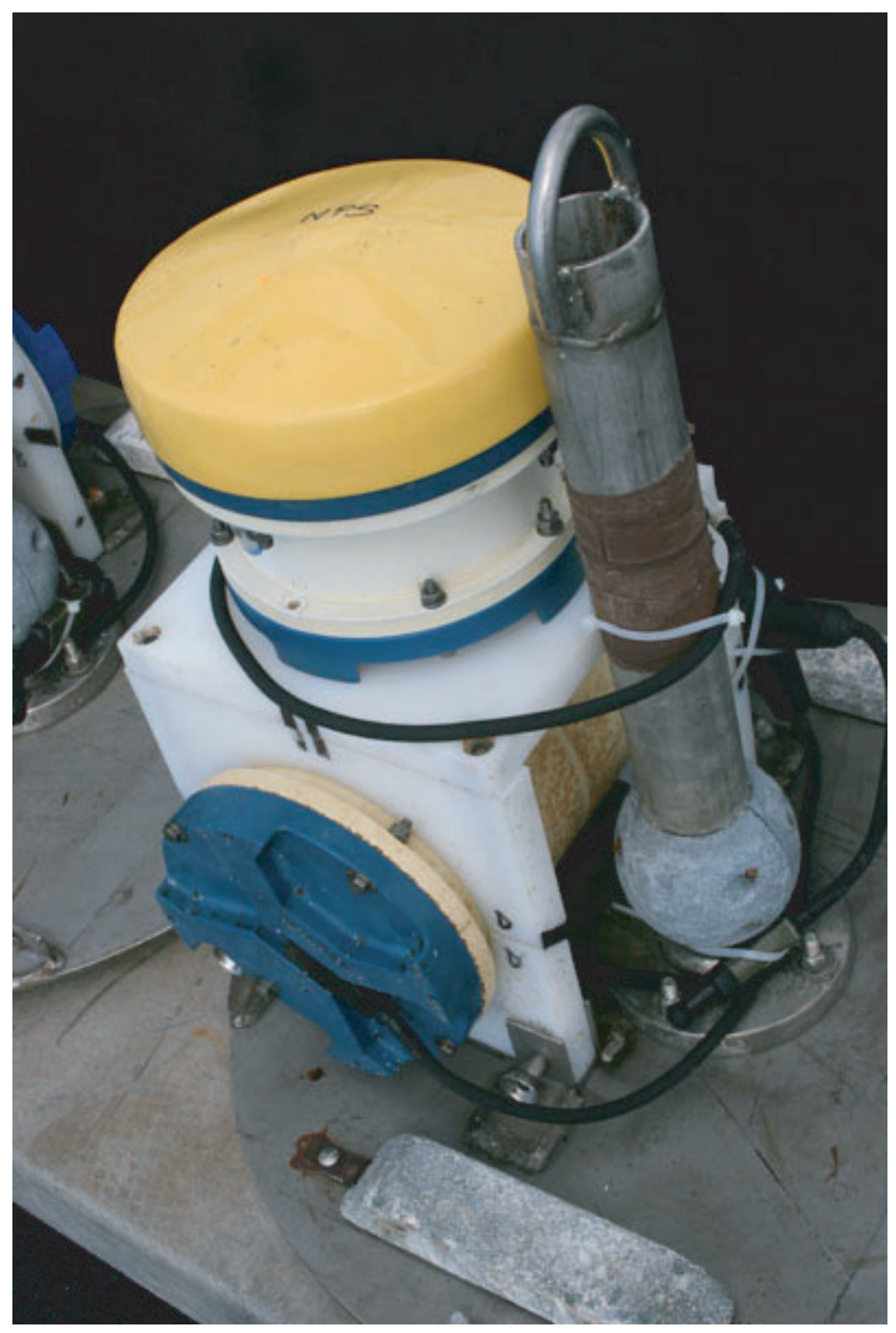

FIGURE 3. Photograph of one of the instrument packages and its mount. The ADCP transducers and the pressure and temperature sensors are under the yellow protective cap ( $20 \mathrm{~cm}$ diameter for scale). 
data from above the surface. All data collected when the beam correlation dropped below $70 \%$ were discarded for visualization and analysis. Post-processed data were saved and copies were desampled to hourly intervals to identify longer-term variability; these desampled copies of the data were also saved and archived.

\section{RESULTS AND DISCUSSION}

This section reviews data collected by both systems during deployment and addresses significance of the findings to characterizing local oceanographic conditions in the study area.

\section{Tides}

Pearl Harbor tides are mixed, microtidal $(<2 m)$ and semi-diurnal with two uneven high tides and two uneven low tides per day; thus the tides change just over every 6 hours. The mean daily tidal range during the study was roughly $0.6 \mathrm{~m}$, while the minimum and maximum daily tidal ranges are $0.4 \mathrm{~m}$ and $0.9 \mathrm{~m}$, respectively.

\section{Currents}

Most daily variability in current speed and direction at the study site is due to the semi-diurnal (12.4 hour) and diurnal (24.8 hour) tides. As the tide rises (floods), currents in Pearl Harbor flow to the north; conversely, as the tide falls (ebbs), the currents flow to the south. Mean current speeds \pm one standard deviation $1 \mathrm{~m}$ above the seafloor are $0.010 \pm 0.007 \mathrm{~m} / \mathrm{sec}$ off the starboard (northwestern) side of the hull (FIGURES 4-5) and $0.027 \pm 0.015 \mathrm{~m} / \mathrm{sec}$ off the port (southeastern) side of the hull (FIGURES 6-7). Higher up in the water column, approximately $1 \mathrm{~m}$ below the water surface, mean current speeds \pm one standard deviation are $0.028 \pm 0.019 \mathrm{~m} / \mathrm{sec}$ off the starboard (northwestern) side of the hull and $0.023 \pm 0.013 \mathrm{~m} / \mathrm{sec}$ off the port (southeastern) side of the hull. Of note are the slightly different orientations in both instantaneous and net flow to the port and starboard sides of the Arizona's hull. Off the starboard side, the flow is predominantly oriented north-northeast or south-southwest, roughly parallel Ford Island's shoreline in the vicinity of the Arizona. Off the port side, however, the flow is predominantly oriented east-northeast or west-southwest, roughly parallel to the main trend of the East Loch of Pearl Harbor. These differences in orientation imply steering, not only by the bathymetry, but also by the Arizona's hull.

The differences in current speed, both vertically and from one side of the hull to the other, result in velocity shear, which, in turn, likely increases turbulence and mixing. The values of vertical shear varied from $0.025 \pm 0.0151 / \mathrm{sec}$ off the starboard (northwestern) side of the hull (FIGURE 8 ) and $0.038 \pm 0.0231 / \mathrm{sec}$ off the port (southeastern) side of the hull (FIGURE 9). The shear was generally highest during the falling tides. The vertical velocity shear, by moving seawater of a given density, would impart a vertical variation in current-induced force on the hull. Seeing that seawater in Pearl Harbor has a density around $1023 \mathrm{~kg} / \mathrm{m}^{3}$ (temperature $25^{\circ} \mathrm{C}$ and a salinity 33 PSU), the mean current-induced force on the starboard (northwestern) side of the hull is $0.175 \pm 0.131 \mathrm{~N} / \mathrm{m}^{2}$ (FIGURE 10) and $0.291 \pm 0.259 \mathrm{~N} / \mathrm{m}^{2}$ on the port (southeastern) side of the hull (FIGURE 11). 

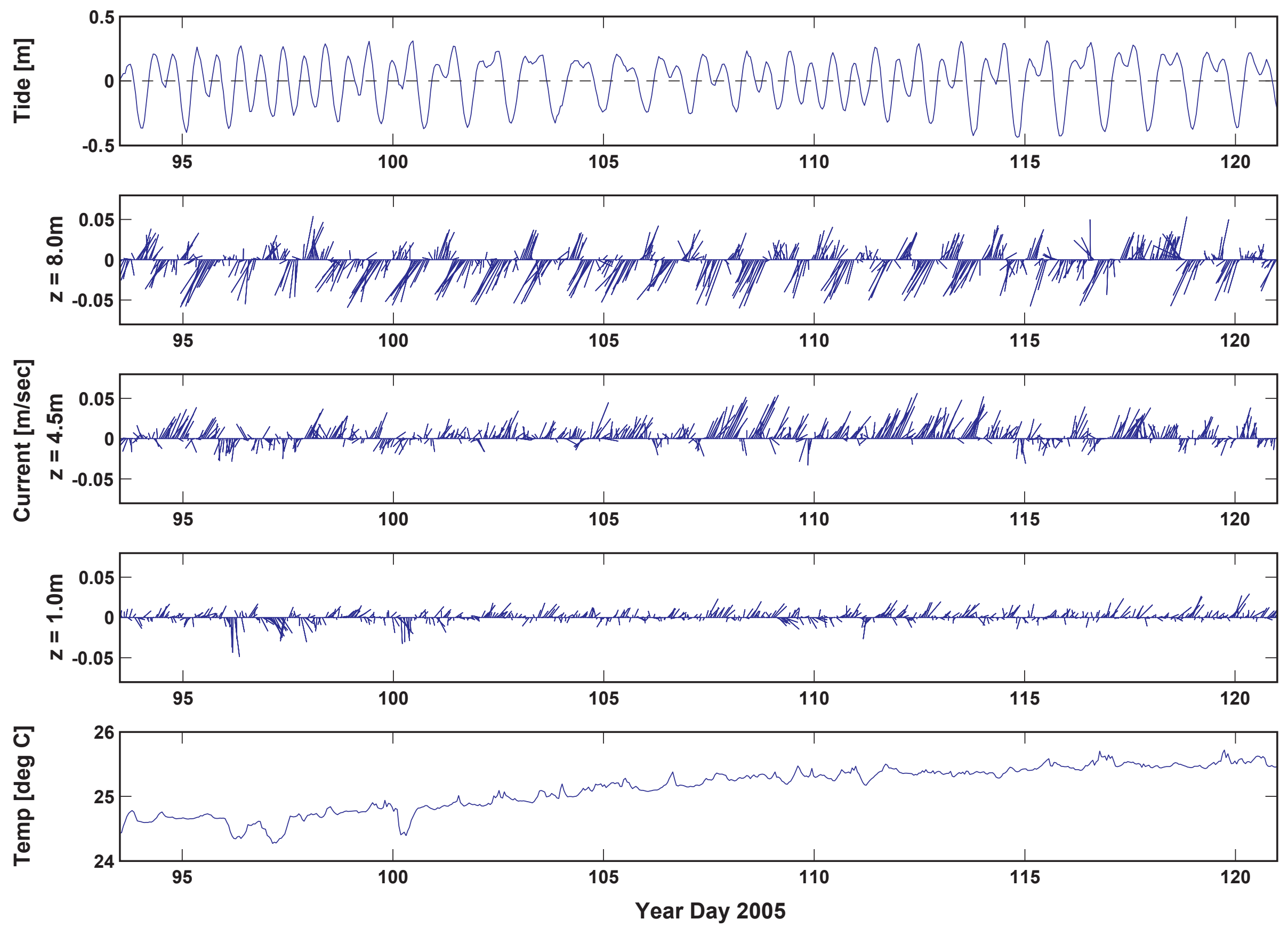

FIGURE 4. Relationship between tides, flow and temperature off the starboard side. The vectors are pointing in the direction of flow and are oriented geographically, with north up and east to the right; z-values are heights above the seafloor. Note the tide ebbs to the southeast and floods to the northwest. 


\section{Principal Axes of Currents}

Uू
है
E्
$>$
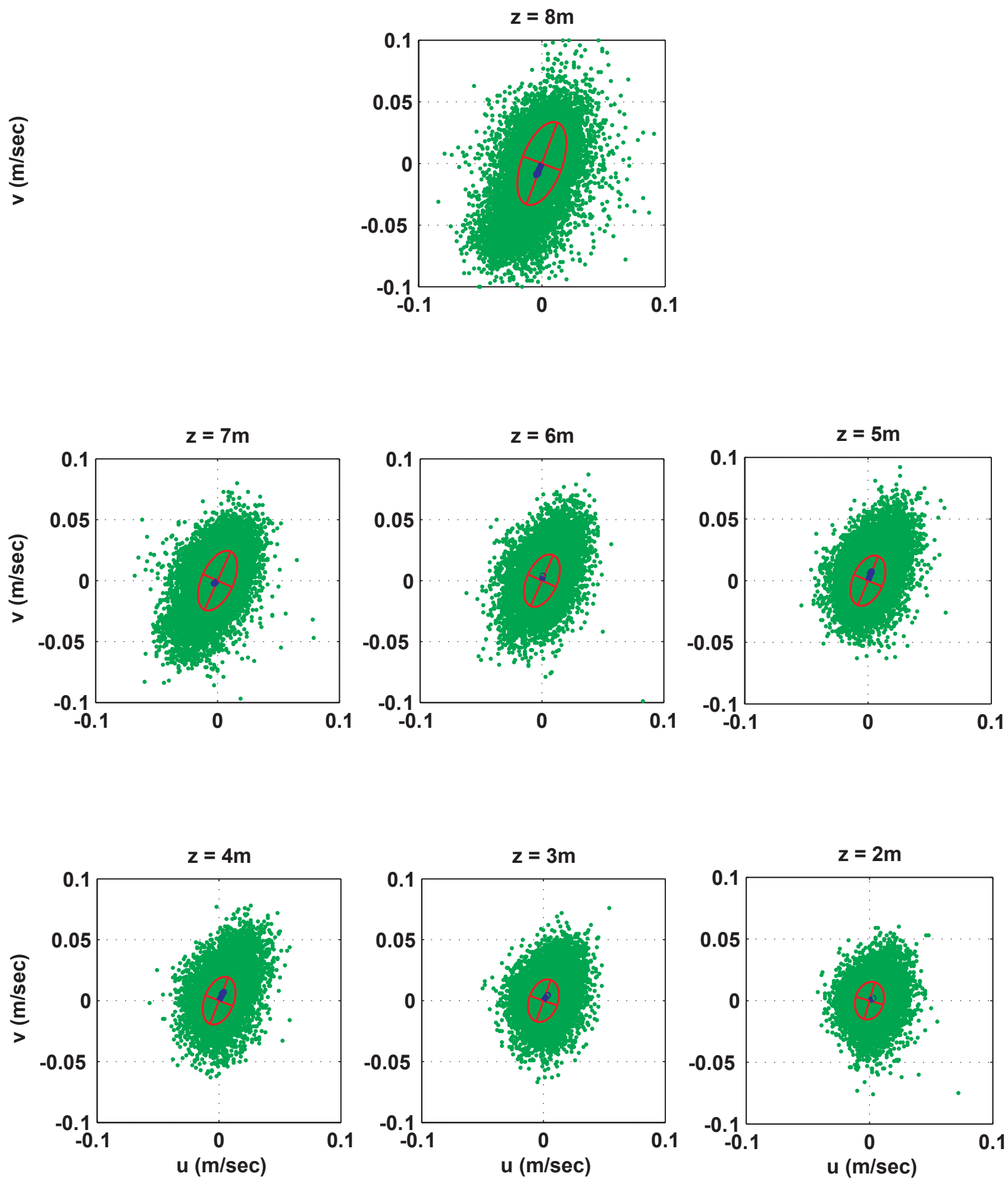

FIGURE 5. Mean flow and its variability at different heights above the seafloor off the starboard side. The measurements are oriented geographically, with north (+v) up and east $(+u)$ to the right; $z$-values are heights above the seafloor. Note the major axis of the current ellipse and mean flow is oriented parallel to the USAR's hull, Ford Island and the southwest-northeast trend of the East Loch. Also note that the flow is weaker and more variable near the seafloor. 

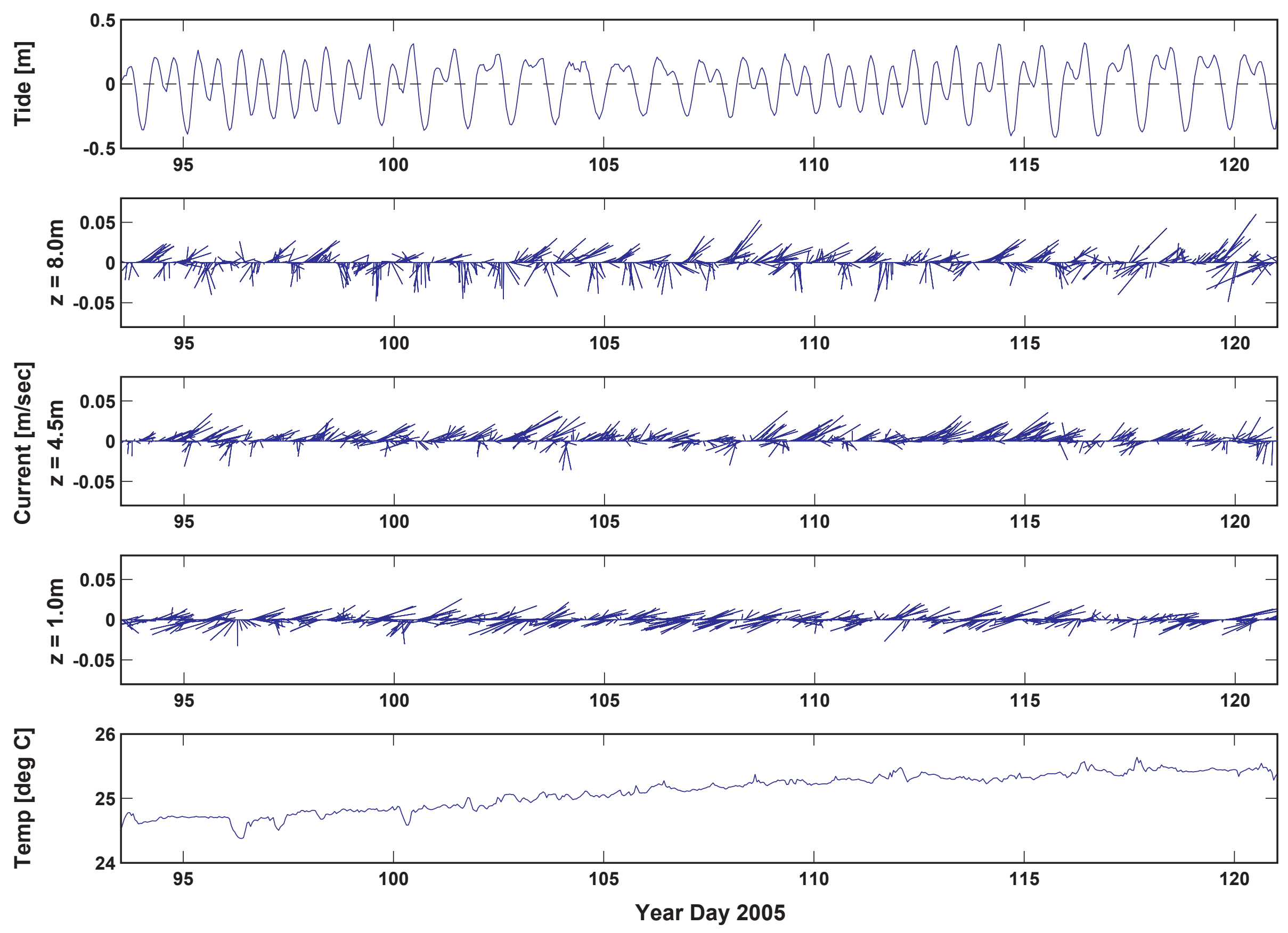

FIGURE 6. Relationship between tides, flow and temperature off the port side. The vectors are pointing in the direction of flow and are oriented geographically, with north up and east to the right; z-values are heights above the seafloor. Note the tide ebbs to the southeast and floods to the northwest. 


\section{Principal Axes of Currents}
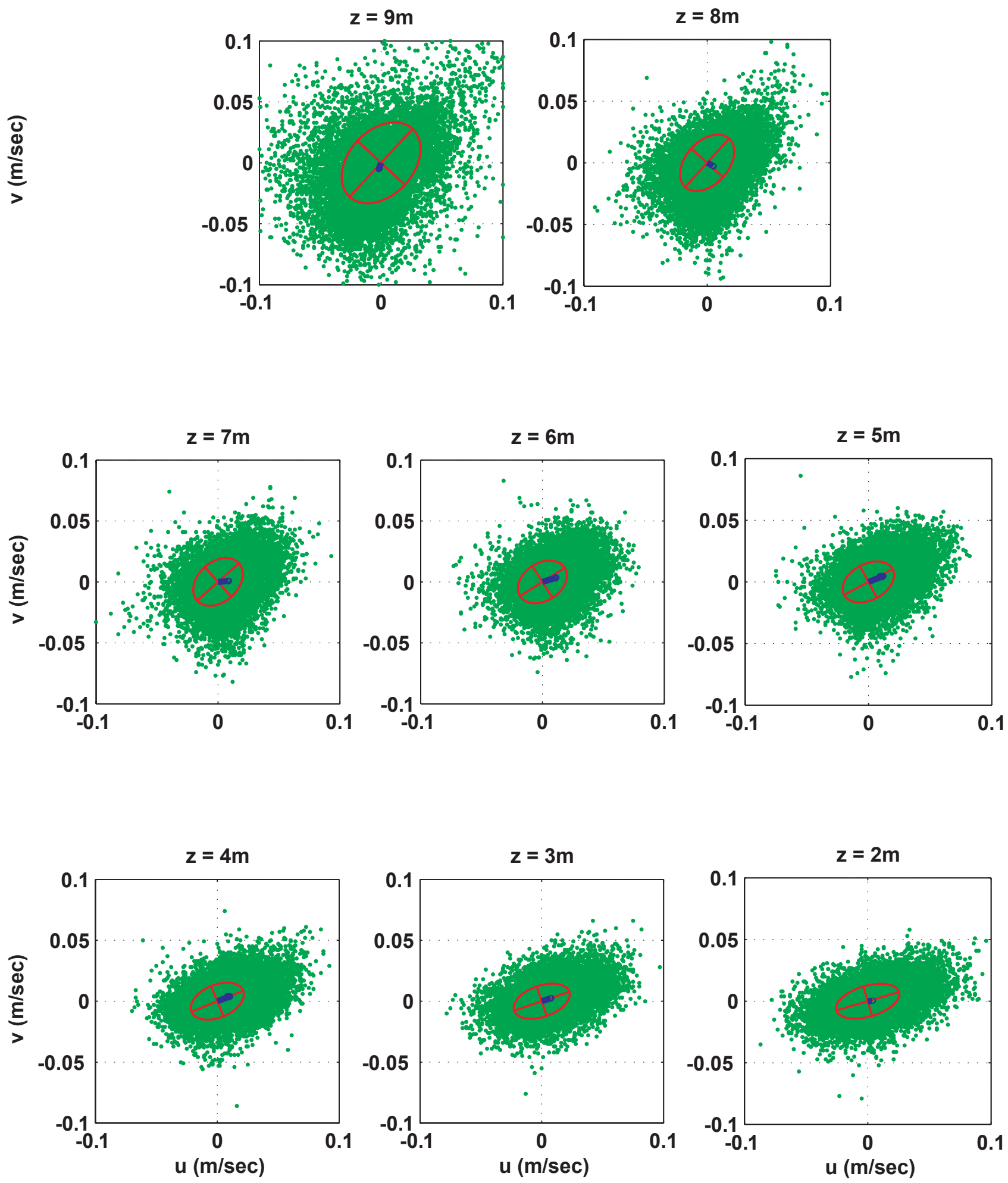

FIGURE 7. Mean flow and its variability at different heights above the seafloor off the port side. The measurements are oriented geographically, with north (+v) up and east ( $+u)$ to the right; $z$-values are heights above the seafloor. Note the major axis of the current ellipse and mean flow is oriented parallel to the USAR's hull, Ford Island and the southwest-northeast trend of the East Loch. Also note that the flow is weaker and more variable near the seafloor. 

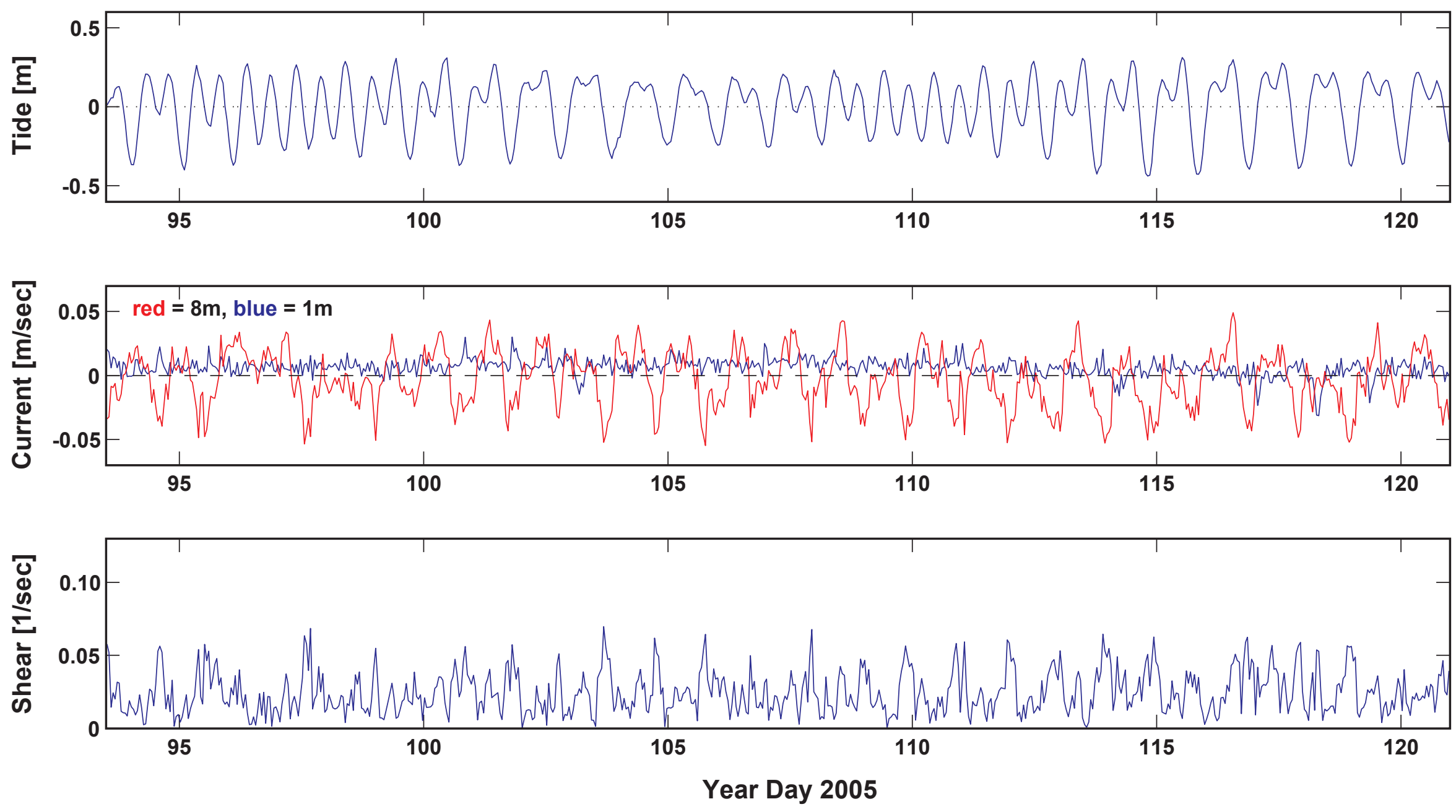

FIGURE 8. Relationship between tides, flow and vertical shear off the starboard side. The current speeds are parallel to the hull; z-values are heights above the seafloor. Note that the shear is due to the strong gradient in current speed through the water column, with the near-surface speeds almost an order of magnitude greater than those near the seafloor. 

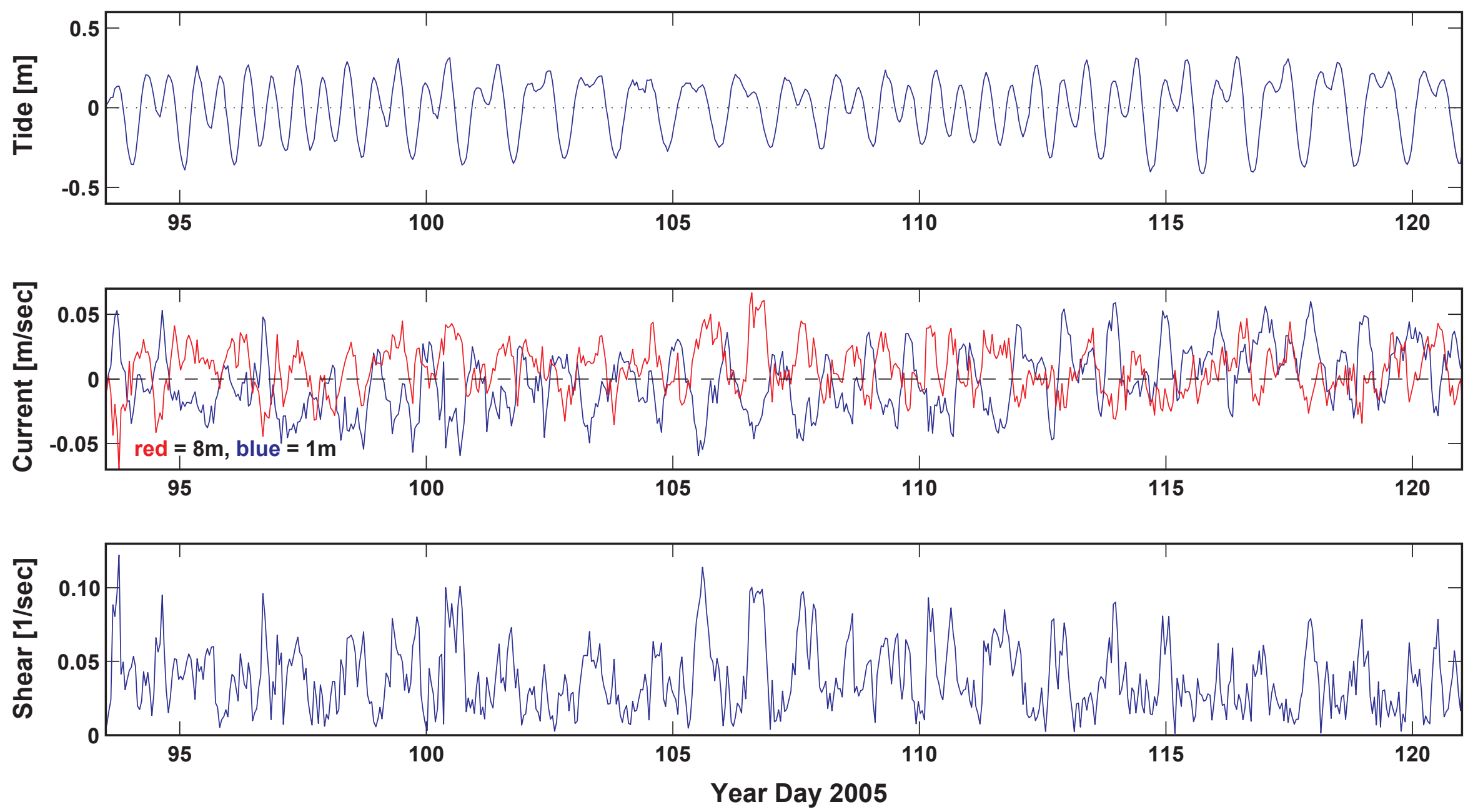

FIGURE 9. Relationship between tides, flow and vertical shear off the port side. The current speeds are parallel to the hull; z-values are heights above the seafloor. Note that unlike of the starboard side of the hull, the shear off the port side is due to the strong gradient in current direction through the water column, with the near-surface speeds often in the opposite direction of those near the seafloor. 

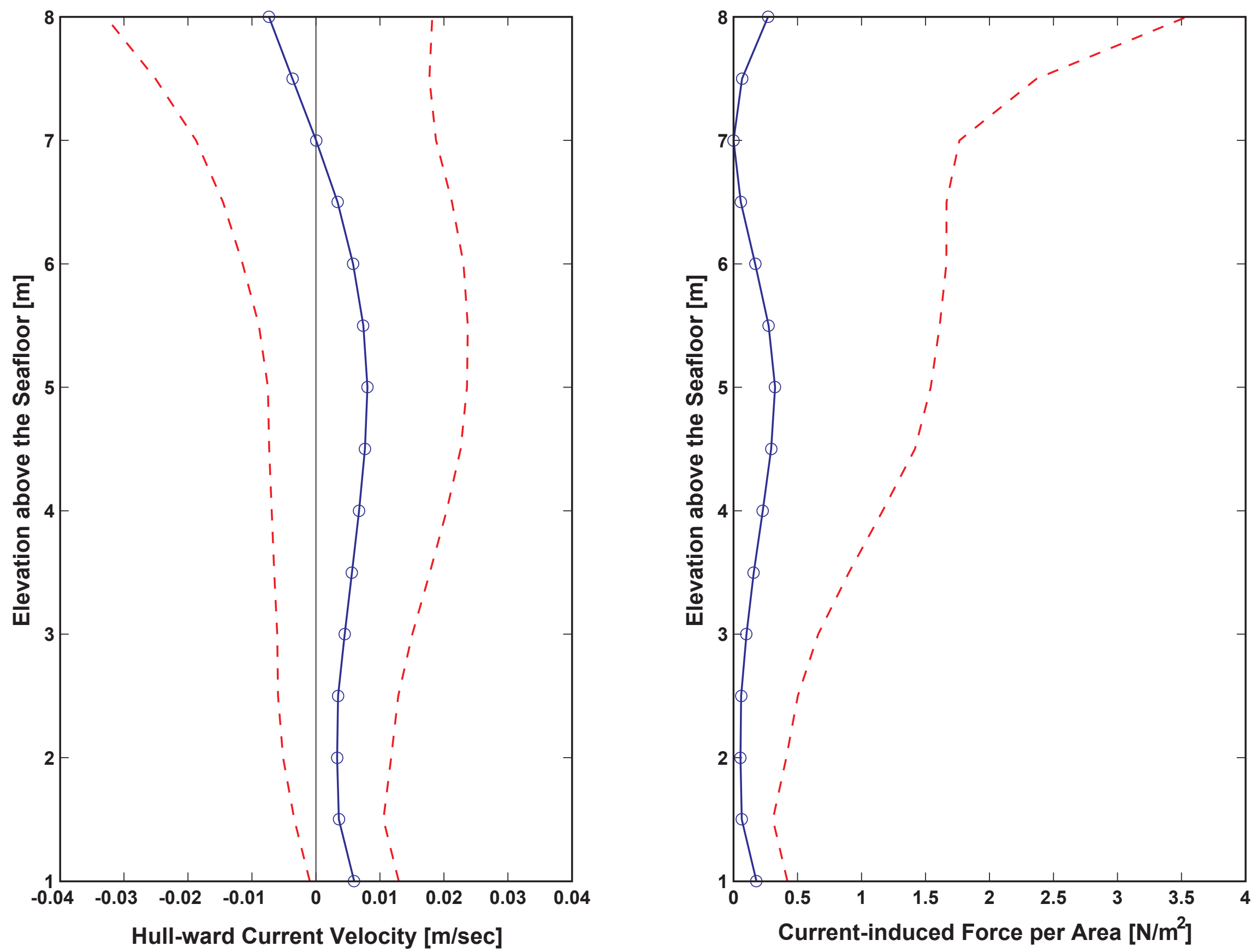

FIGURE 10. Vertical profiles of current velocity and the resulting current-induced force on the starboard hull. Dashed red lines are \pm 1 standard deviation. Note that flow is towards the hull throughout most of the water column but is away from the hull at the surface. 

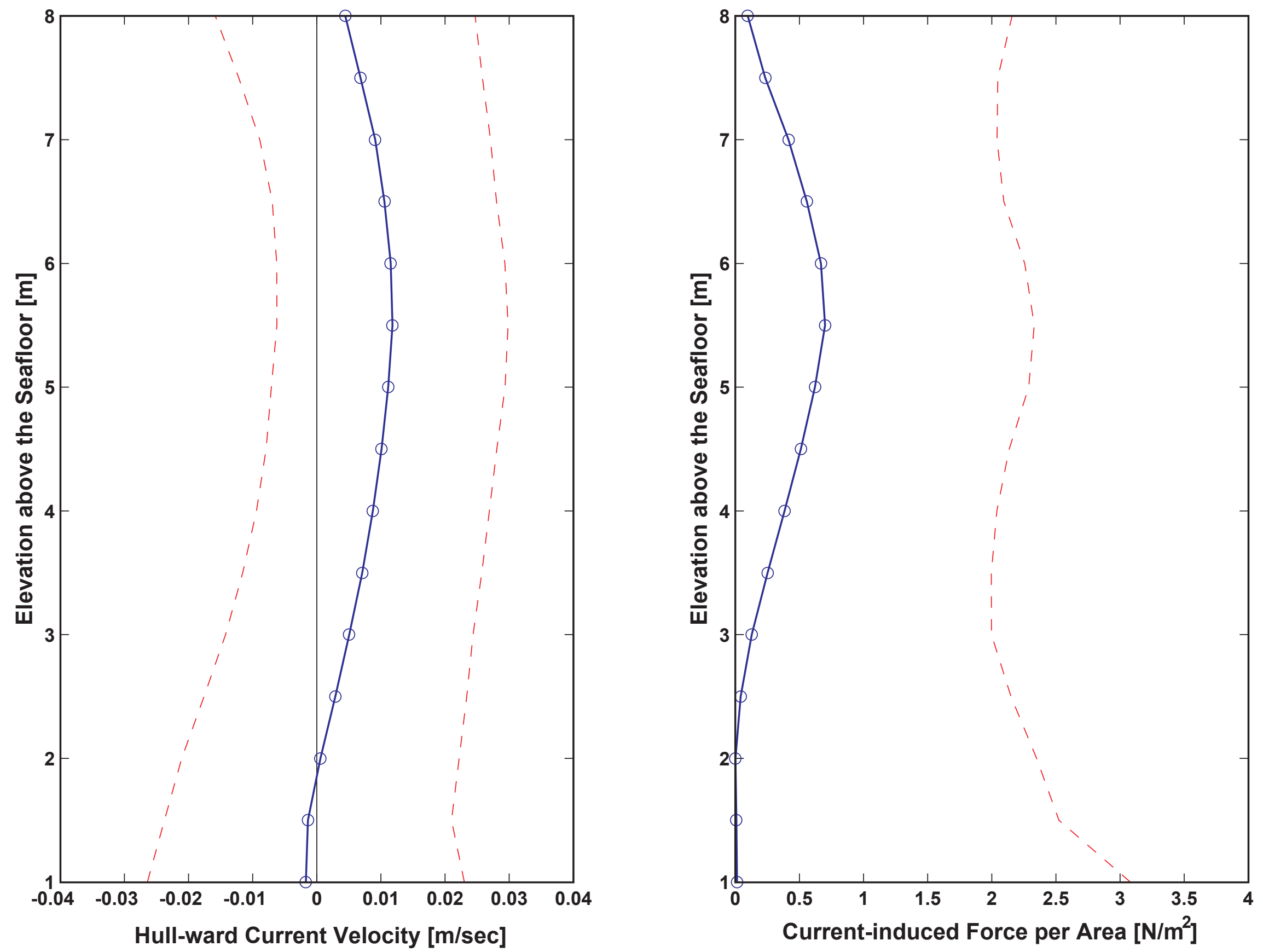

FIGURE 11. Vertical profiles of current velocity and the resulting current-induced force on the port hull. Dashed red lines are \pm 1 standard deviation. Note that flow is towards the hull throughout the entire water column except near the bed. 
Assuming flow speeds remained constant, the mean current s measured would result in a total replacement of water along the $185 \mathrm{~m}$ length of the hull in 1.84 to 5.14 hours off the starboard (northwestern) side of the hull at the surface and the seafloor, respectively, and 2.23 to 1.90 hours off the port (southeastern) side of the hull at the surface and the seafloor, respectively. Because the shear-induced turbulence enhances these mean flow speeds, the actual replenishment time would probably be shorter. The orientation of greatest flow variability and mean flow is approximately parallel to the hull, Ford Island and the southwest-northeast trend of the East Loch throughout most of the water column. Close to the bed, however, the orientation of flow becomes less distinct and sometime orthogonal to the hull (trending east-west), similar to the long-term near-bed observations made by Storlazzi et al. (2004).

The lunar tidal cycle drives the magnitude of the tidal currents, with the highest tidal current speeds occurring during spring tides (new and full moons) and the weakest during neap tides (quarter moons). While tides control the majority of the variability in current speed and direction, insolation-driven Trade wind intensification also appears to slightly influence daily variability. When the Trade winds blow at high speed in the early to late afternoon, the net flow appears to take on a more northerly component. This shift might be due to the Trade winds blowing obliquely onshore to the northwest along Oahu's southern shoreline, which forces oceanic water up into Pearl Harbor. We do not have information at this time that indicates which process or combination of processes is responsible for the observed intensification of northeasterly flow during the afternoon.

\section{Temperature}

Over the period of study, the water off the starboard (northwestern) side of the hull at a depth of $9 \mathrm{~m}$ had a mean temperature \pm one standard deviation of $25.11 \pm 0.35$ ${ }^{\circ} \mathrm{C}$ and at a depth of $10 \mathrm{~m}$ off the port (southeastern) side of the hull the mean temperature \pm one standard deviation was $25.10 \pm 0.29^{\circ} \mathrm{C}$ (FIGURE 12). Overall, the variability in water temperature was greater off the starboard (northwestern) side of the hull between the hull and Ford Island. In general, the near-bed water off the starboard (northwestern) side of the hull was slightly $\left(0.02 \pm 0.10^{\circ} \mathrm{C}\right.$ ) warmer that off the port (southeastern) side of the hull. The greater stability off the port (southeastern) side of the hull is likely caused by greater mixing due to currents, which act to minimize temperature fluctuations caused by insolation or submarine groundwater discharge. We do not have information at this time that indicates that these processes are the cause of the temperature differences between the two sites. At both sites, insolation typically warmed the water during the day by approximately $0.1^{\circ} \mathrm{C}$.

\section{CONCLUSIONS}

In all, more than 580,000 observations of currents and near-bed water temperatures were collected during April, 2005, in Pearl Harbor, Oahu, Hawaii, USA. Significant findings based upon these measurements and analyses include:

(1) Tides are of mixed, semi-diurnal type with a minimum, mean and maximum tidal range of $0.4 \mathrm{~m}, 0.6 \mathrm{~m}$ and $0.9 \mathrm{~m}$, respectively. 

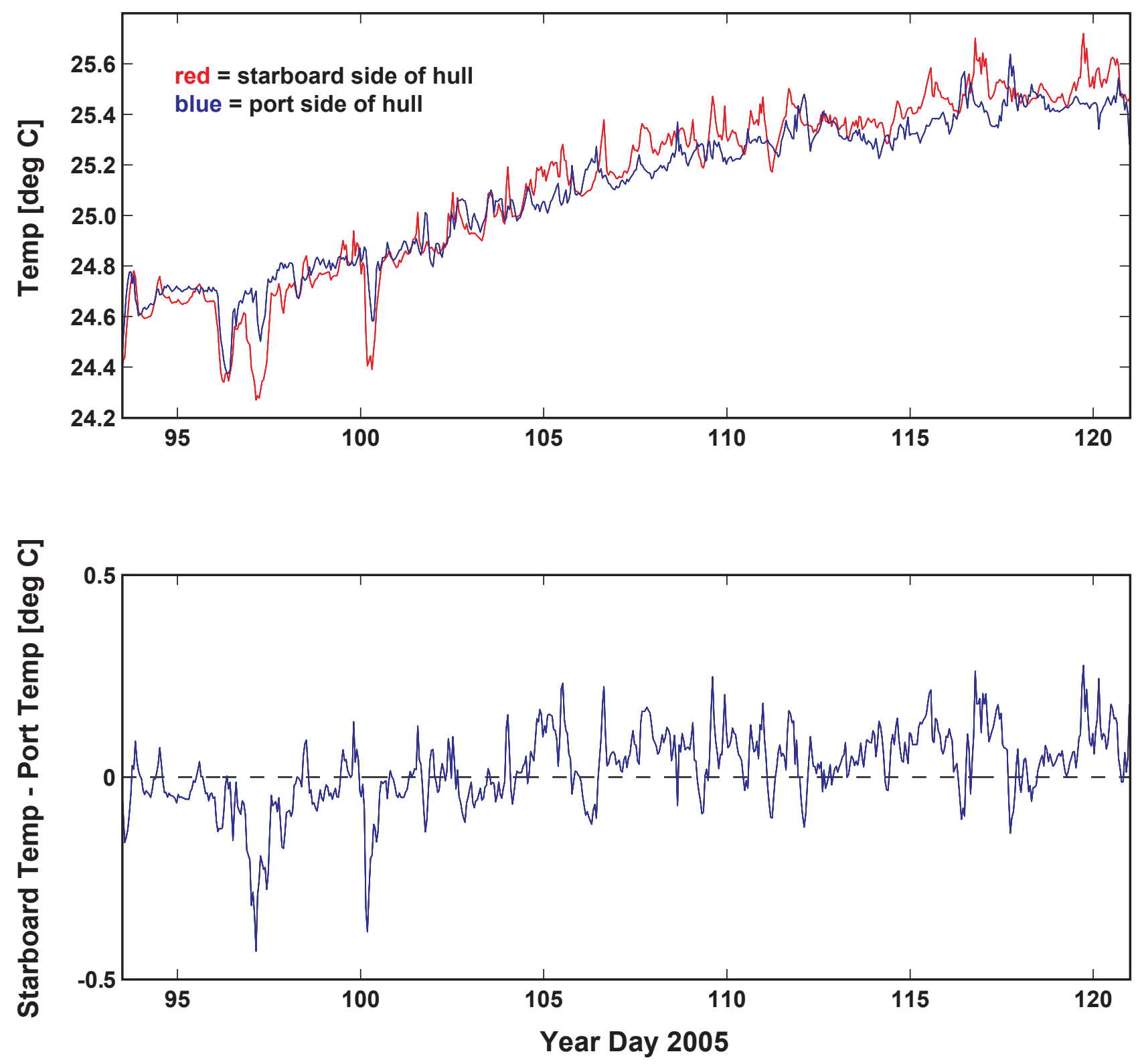

FIGURE 12. Concurrent water temperatures off the port and starboard sides of the hull and the resulting thermal gradient. While both the port and starboard temperatures both follow the same long-term trends, note the greater fluctuations in water temperature off the starboard side; this likely results from less mixing of the water column off the starboard side. 
(2) Flow along the hull is dominated by semi-diurnal and diurnal tidal motions, which are modulated to some degree by what appears to be wind forcing during the mid- to late afternoon. Flow throughout most of the water column is primarily parallel to the Arizona's hull at $\sim 0.02 \mathrm{~m} / \mathrm{sec}$ and net flow is to the northeast. Flow within a meter of the seafloor, however, is weaker and more variable in direction.

(3) Flow speeds are faster off the port side than the starboard side, and thus the water replenishment times on the port side of the hull are shorter than off the starboard side.

(4) Shear, both vertically in the water column and across the hull, was observed. This results in vertical variations in replenishment times and current-induced forces on the hull. This shear also likely increases vertical mixing of the water column.

(5) Water temperatures were generally cooler and less variable off the port side of the hull than off the starboard side, possibly due to faster replenishment times and greater mixing of the water column.

These data provide us with a much clearer picture of the nature of and controls on the fluid flow around USS Arizona's hull in Pearl Harbor, Oahu, Hawaii. The complexity of the physical environment surrounding and influencing Arizona is reflected in the number of interesting phenomena observed during this one month study.

\section{ACKNOWLEDGEMENTS}

This work was carried out as part of a NPS-USGS partnership as part of an effort in the U.S. and its trust territories to better understand and characterize the nature of and variability in coastal processes. NPS-SRC Chief Larry Murphy and USGS Project Chief Michael Field deserve thanks for providing us with the patience, opportunity and support to carry out this work. Joshua Logan (USGS) assimilated the NPS GIS data and produced the maps presented in this report. We would also like to thank Jodi Eshleman (USGS) and Ann Gibbs (USGS), who contributed numerous excellent suggestions and a timely review of our work.

\section{REFERENCES}

Storlazzi, C.D., Russell, M.A., Owens, M.D., Field, M.E. and Murphy, L.E., 2004. "Dynamics of the Physical Environment at the USS Arizona Memorial: 2002-2004" U.S. Geological Survey Open-File Report 2004-1353, 28 p.

http://pubs.usgs.gov/of/2004/1353/ 


\section{TABLE 1. Experiment personnel}

\begin{tabular}{|l|l|l|}
\hline \multicolumn{1}{|c|}{ Person } & \multicolumn{1}{|c|}{ Affiliation } & \multicolumn{1}{c|}{ Responsibilities } \\
\hline Curt Storlazzi & USGS & Chief scientist, scuba diver \\
Matthew Russell & NPS-SRC & Co-chief scientist, led scuba diving operations \\
Kathy Presto & USGS & Scientist, lead instrument technician \\
Jennifer Burbank & NPS-USAR Memorial & USAR Memorial ranger, diver, led recovery operations \\
Joshua Logan & USGS & Scientist, diver, GIS tecchnician \\
Thomas Reiss & USGS & Scientist, dive safety officer \\
\hline
\end{tabular}

\section{TABLE 2. ADCP deployment log}

\begin{tabular}{|l|c|c|c|c|c|c|}
\hline Instrument & Island ID & $\begin{array}{c}\text { Depth } \\
(\mathrm{m})\end{array}$ & $\begin{array}{c}\text { Deployment } \\
\text { Date }\end{array}$ & $\begin{array}{c}\text { Recovery } \\
\text { Date }\end{array}$ & $\begin{array}{c}\text { Latitude } \\
(\mathrm{dd})\end{array}$ & $\begin{array}{c}\text { Longitude } \\
(\mathrm{dd})\end{array}$ \\
\hline Starboard & OA & 9 & $4 / 2 / 2005$ & $5 / 1 / 2005$ & 21.364684 & -157.950756 \\
Port & OA & 10 & $4 / 2 / 2005$ & $5 / 1 / 2005$ & 21.364206 & -157.950550 \\
\hline
\end{tabular}




\section{APPENDIX 1}

Acoustic Doppler Current Profiler (ADCP) Information

Instrument:

RD Instruments $600 \mathrm{kHz}$ Workhorse Monitor; s/n: 2074

RD Instruments 600 kHz Workhorse Monitor; s/n: 2432

Transmitting Frequency:

Depth of Transducer:

Blanking Distance:

Height of First Bin above Bed:

Bin Size:

Number of Bins:

Operating Mode:

Sampling Frequency:

Beam Angle:

Time per Ping:

Pings per Ensemble:

Ensemble Interval:

Sound Speed Calculation:
$614 \mathrm{kHz}$

$10 \mathrm{~m}$

$0.30 \mathrm{~m}$

$0.80 \mathrm{~m}$

$0.5 \mathrm{~m}$

28

High-resolution, broad bandwidth

$4 \mathrm{~Hz}$

$20 \mathrm{deg}$

00:00:00.30

1

00:04:00.00

Set salinity, updating temperature via sensor

Data Processing:

The data were averaged over 20-bin (1 hour) ensembles, all of the spurious data above the water surface were removed and all of the data in bins where the beam correlation dropped below $70 \%$ were removed for visualization and analysis.

Position Information:

Garmin GPS-76 GPS; s/n: 80207465; USGS/CRP unit\#1

$\mathrm{RDI}$ internal compass/gyroscope, set to -10 deg magnetic offset 